\title{
Antioxidant activity and physico-chemical analysis of Campomanesia rufa (O.Berg) Nied. fruits
}

\section{Atividade antioxidante e análise físico-química de frutos de Campomanesia rufa (O.Berg) Nied.}

\author{
Letícia Aparecida Ferreira de Abreu ${ }^{1}$ (D) Renato Paiva1 ${ }^{1 D}$, Judith Georgette Alcalde Mosqueira ${ }^{1 *}$ (iD), \\ Michele Valquíria dos Reis ${ }^{(D)}$, Ana Beatriz Silva Araújo ${ }^{3}$ (D) Eduardo Valério de Barros Vilas Boas ${ }^{3}$ (D)
}

\author{
'Universidade Federal de Lavras/UFLA, Departamento de Biologia/DBI, Lavras, MG, Brasil \\ ${ }^{2}$ Universidade Federal de Lavras/UFLA, Departamento de Agronomia/DAG, Lavras, MG, Brasil \\ ${ }^{3}$ Universidade Federal de Lavras/UFLA, Departamento de Ciências dos Alimentos/DCA, Lavras, MG, Brasil \\ ${ }^{*}$ Corresponding author: judithalcalde9@gmail.com \\ Received in June 9, 2020 and approved in September 21, 2020
}

\begin{abstract}
Campomanesia rufa (O. Berg) Nied. is a native Cerrado species that presents great edible potential. However, it is a species "in danger of extinction" as recommended by the International Union for the Conservation of Nature (IUCN). No technical and scientific information about the species exists, thus demonstrating the importance of its research. The present work aimed at the physical and chemical characterization of immature and mature $C$. rufa fruits. The fruits showed a change in coloration from green $(b *=25.11, h=122.43)$ to yellowish-green ( $\left.^{*}=34.26, \mathrm{~h}=115.73\right)$, an increase in mass ( $6.54 \mathrm{~g}$ to $10.88 \mathrm{~g}$ ), diameter ( $23.76 \mathrm{~mm}$ to $28.03 \mathrm{~mm}$ ) and soluble solids

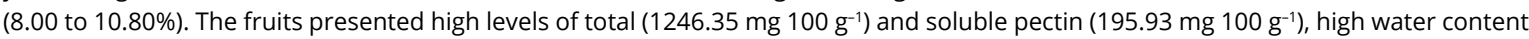

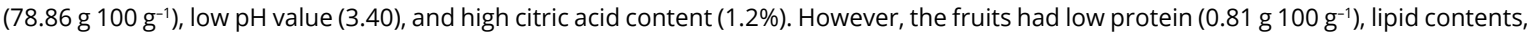

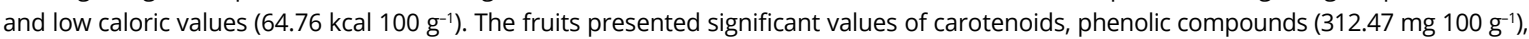
vitamin C (263.60 mg $\left.100 \mathrm{~g}^{-1}\right)$ as well as good in vitro antioxidant activity $\left(1862.81 \mu \mathrm{M} \mathrm{g}^{-1}\right)$. The results obtained indicate that $\mathrm{C}$. rufa fruits showed a similar composition to the fruits of other Campomanesia species, and their biological properties should be investigated additionally under in vivo conditions.
\end{abstract}

Index terms: Cerrado; Myrtaceae; casaqueira; endangered species; vitamin C.

\begin{abstract}
RESUMO
Campomanesia rufa (O. Berg) Nied. é uma espécie nativa do Cerrado que apresenta grande potencial comestível. No entanto, é uma espécie "em perigo de extinção", segundo a União Internacional para a Conservação da Natureza (IUCN). Não existe informação técnica e científica sobre a espécie, demonstrando a importância das pesquisas. O presente trabalho teve como objetivo a caracterização físicoquímica de frutos imaturos e maduros de C. rufa. Os frutos apresentaram alteração na coloração de verde ( $b$ * $=25.11, h=122.43)$ para verde amarelado ( $\mathrm{b} *=34.26, \mathrm{~h}=115.73)$, aumento na massa (6.54 g para $10.88 \mathrm{~g})$, diâmetro $(23.76 \mathrm{~mm}$ a $28.03 \mathrm{~mm}$ ) e sólidos solúveis (8.00 a 10.80\%). Os frutos apresentaram altos teores de pectina total (1246.35 mg $100 \mathrm{~g}^{-1}$ ) e solúvel (195.93 mg $\left.100 \mathrm{~g}^{-1}\right)$, alto teor de água (78.86 $\left.100 \mathrm{~g}^{-1}\right)$, baixo valor de pH (3.40) e alto ácido cítrico conteúdo (1.2\%). No entanto, os frutos apresentaram baixo teor de proteína

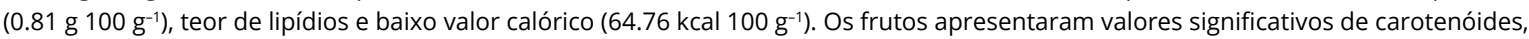

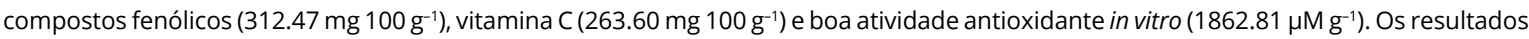
obtidos indicam que os frutos de C. rufa apresentam composição semelhante aos frutos de outras espécies de Campomanesia, e suas propriedades biológicas devem ser investigadas adicionalmente em condições in vivo.
\end{abstract}

Termos para indexação: Cerrado; Myrtaceae; casaqueira; espécie ameaçada de extinção; vitamina C.

\section{INTRODUCTION}

The Cerrado biome occupies $22 \%$ of the Brazilian territory and houses a vast and diverse genetic heritage that is unique in the world (Reis; Schmiele, 2019). The Cerrado holds $40 \%$ of the endemic plant species and one-third of all
Brazilian biodiversity (Luz et al., 2019). Many of the native Cerrado species produce fruits with commercial potential for natural consumption and the production of derivatives such as juices, jellies, and liquors (Neves et al., 2015). In addition, they can also be employed to obtain secondary metabolites such as phenolic compounds, antioxidants, 
and antiproliferative agents of human carcinogenic cells (Araújo et al., 2018).

However, there is a large deficit of scientific studies on the native Cerrado species (Arruda; Pastore, 2019). This reduces the possibilities of developing new products and expanding the use of species already consumed by the local populations (Carvalho et al., 2019). For this reason, scientific studies were focused on properties and the uses of native plants (Arruda; Pastore, 2019).

The Myrtaceae family is second in terms of diversity in the phytogeographical domain of the Cerrado (Silvestre; Miranda; De-Carvalho, 2019). The Campomanesia genus belongs to the Myrtaceae family and possesses food, ornamental, and pharmaceutical potential (Zuninga et al., 2018; Carvalho et al., 2019). It has a limited distribution in the phytogeographical domains of the Atlantic and Cerrado Forest in Minas Gerais state, Brazil (Reflora, 2020).

Chemical studies with Campomanesia genera such as Campomanesia adamantium, Campomanesia pubescens, Campomanesia cambessedeana, Campomanesia corimbosa, Campomanesia aurea, Campomanesia xanthocarpa, Campomanesia guazumifolia, Campomanesia reitziana, and Campomanesia lineatifolia showed high content of phenolic compounds, antioxidants, and vitamin C (Sá et al., 2018; Cardozo et al., 2018; De Andrade Silva; Fonseca, 2016; Da
Silva et al., 2016; Emer et al., 2018; Salmazzo et al., 2019; De Souza Duarte et al., 2020).

Campomanesia rufa is used by the local population. However, studies on C. rufa are scarce (Sant'Ana et al., 2018). It is classified as being 'vulnerable' by the Red List maintained by the International Union for Conservation of Nature-IUCN (1998), thus demonstrating the importance of exploratory studies with the species. Such studies will enable us to understand how these fruits can be utilized commercially in a better manner (Araújo et al., 2018).

Given the above arguments, this work aimed to characterize the physical and chemical properties of C. rufa during the immature and mature stages of development.

\section{MATERIAL AND METHODS}

\section{Plant material}

Immature and mature fruits of C. rufa (Figure 1) were collected from a natural population located at $21^{\circ}$ 13 '35.5" S latitude and $44^{\circ} 59^{\prime} 00.7^{\prime \prime} \mathrm{W}$ longitude in the region of Lavras, Minas Gerais state, Brazil. The climate in this region is characterized as a rainy season with dry winters and rainy summers with an average annual temperature of $19^{\circ} \mathrm{C}$ and an average annual rainfall of $1,530 \mathrm{~mm}$.

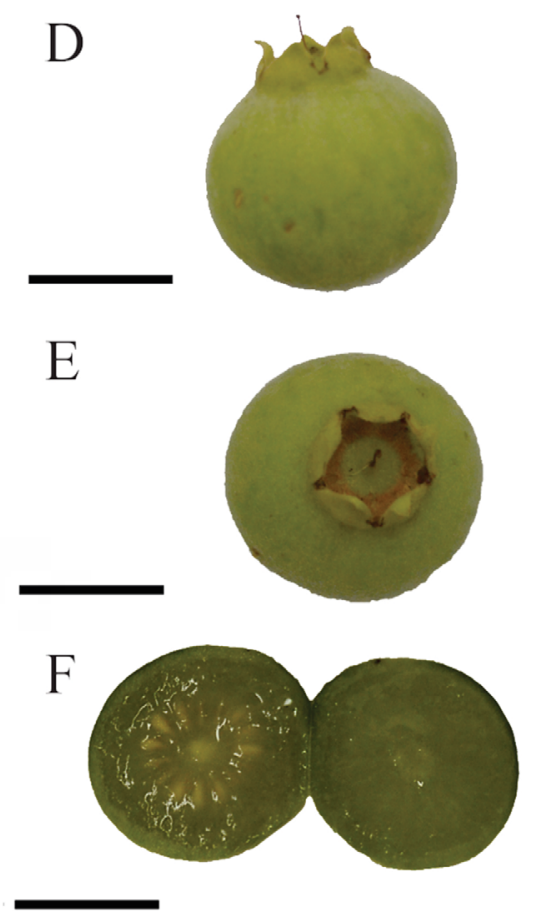

Figure 1: Fruits of Campomanesia rufa.

Representation of immature fruits $(A, B$, and $C)$ and mature fruits $(D, E$, and $F)$. Bar $=2 \mathrm{~cm}$. 
The identification of the species was carried out by cross-checking with the plants maintaned in the ESAL Herbarium of the Federal University of Lavras with the collection number ESAL21198. Seeds with incomplete embryo development were considered immature fruits, and those with complete embryo development were considered mature fruits. For the analysis, both stages of fruits were used.

\section{Diameter, mass, and pulp yield}

The mean longitudinal and transverse diameters of the fruits were determined using a digital caliper. The average mass of the fruits was determined by the individual weighing of the fruits on a semianalytic scale.

To calculate the pulp yield, the initial weight of the ripe fruit, and the weight of the pulp was measured. The calculation was performed using the following equation: pulp weight/fruit weight $* 100$.

\section{Color and firmness}

The staining was determined using a Konica Minolta CR-400 colorimeter calibrated according to the CIE system with $L^{*}, a^{*}, b^{*}, h$, and $C^{*}$ (Illuminant D65). The $\mathrm{L}^{*}$ coordinate represented the brightness with values between 0 (totally black) and 100 (totally white). The coordinate $\mathrm{a}^{*}$ assumed values between -80 to +100 in which the ends corresponded to green and red, respectively. The $b^{*}$ coordinate ranged from -50 to +70 with blue to yellow intensity. The hue angle $(\mathrm{h})$ corresponded to the hue and identified the color between $0^{\circ}$ and $360^{\circ}$ and the Chroma $\left(\mathrm{C}^{*}\right)$ was saturation or intensity of the color as outlined by McGuire (1992).

The firmness was determined in a Stable Micro System model TATX2i texturometer using the $\mathrm{P} / 6 \mathrm{~N}$ probe ( $2 \mathrm{~mm}$ in diameter). The penetration force of the fruits was measured at a speed of $5 \mathrm{~mm} / \mathrm{s}$ and with a penetration distance of $30 \mathrm{~mm}$ with values previously determined. An HDP/90 platform was used as the base. The firmness of the fruits was expressed in Newton $(\mathrm{N})$.

\section{Titratable Acidity (AT), pH, Soluble Solids (SS), and SS/AT ratio}

The determination of titratable acidity (AT) was performed by titration with a $0.01 \mathrm{M}$ sodium hydroxide solution $(\mathrm{NaOH})$ using phenolphthalein as an indicator according to methods from the (Adolfo Lutz Institute IAL, 2005). The results were expressed as percent citric acid. The $\mathrm{pH}$ of the pulp was determined using a TEC-3 MP Tecnal ${ }^{\circledR} \mathrm{pH}$ meter according to the technique of the Adolfo Lutz Institute (IAL, 2005). The soluble solids content (SS) was determined using a digital refractometer, and the results were expressed in percentage. The soluble solids/titratable acidity ratio (SS/AT ratio) was determined by dividing the first variable by the second variable (IAL, 2005).

\section{Proximate analysis}

Proximate analysis (g $\left.100 \mathrm{~g}^{-1}\right)$ was performed according to the methods proposed by (Association of Official Analytical Chemistry - AOAC, 2012). The moisture content was determined by oven drying at $65^{\circ} \mathrm{C}$ until a consistent weight was reached. The lipid content was determined in a Soxhlet apparatus. The protein content was determined by the Kjeldahl method considering a conversion factor of 6.25 . The crude fiber was determined by the gravimetric method. Ash determination was performed by the gravimetric method of incineration in a muffle furnace at $550^{\circ} \mathrm{C}$. Nitrogen-free extract (NFE) was determined from the formula: NFE $=100$ - (moisture + lipids + proteins + fiber + ash). The results of the proximate analyses were expressed in $\mathrm{g} 100 \mathrm{~g}^{-1}$. The caloric value was estimated using Atwater's conversion values: $9 \mathrm{kcal}$ per $\mathrm{g}$ of lipids, $4 \mathrm{kcal}$ per $\mathrm{g}$ of protein, and $4 \mathrm{kcal}$ per $\mathrm{g}$ of carbohydrates (De Angelis, 1977).

\section{Total and Soluble Pectin}

The extraction of pectic substances was performed according to the technique described by McCready and McComb (1952). Here, $5 \mathrm{~g}$ of fresh fruit was homogenized with $45 \mathrm{~mL}$ of $70 \%$ ethyl alcohol and the homogenate was left to stand for $18 \mathrm{~h}$ to remove the total sugars. Subsequently, the homogenate was filtered and washed thrice with $30 \mathrm{~mL}$ of $70 \%$ ethyl alcohol. The filtrate was used to determine the total sugars, and the alcoholinsoluble residue (AIR) was homogenized with $50 \mathrm{~mL}$ of distilled water for $1 \mathrm{~h}$ and again filtered to determine the soluble pectin.

For the determination of total pectin, $50 \mathrm{~mL}$ of versene solution ( $0.5 \%$ EDTA) was added to the homogenate (after the removal of sugars), and the $\mathrm{pH}$ was increased to 11.5 with $\mathrm{NaOH}$ solution. The mixture was allowed to stand for $30 \mathrm{~min}$, and the $\mathrm{pH}$ was reduced to 5.5 using acetic acid. Further, $0.1 \mathrm{~g}$ of pectinase was added and stirred for $1 \mathrm{~h}$. The mixture was filtered, and a total volume of $100 \mathrm{~mL}$ was obtained with versene solution.

For the determination of soluble pectin (after the extraction of sugars), the filtered residue (AIR) was placed in Erlenmeyer flasks, and $50 \mathrm{~mL}$ of distilled water was added. It was then homogenized on a shaker for $1 \mathrm{~h}$ and filtered with a quantitative filter paper. 
The colorimetric quantification was performed by the technique of Bitter and Muir (1962). The results were expressed in $\mathrm{mg}$ of galacturonic acid $100 \mathrm{~g}^{-1}$ of pulp.

\section{Total Sugars}

The filtrate obtained from pectin extraction (AIR) was heated for evaporation of the alcohol until the volume was reduced to $10 \mathrm{~mL}$. Distilled water was added to make a final volume of $50 \mathrm{~mL}$. This solution was used for the quantification of sugars by the method of Somogyi adapted by Nelson (1944), and results were expressed in $g$ of glucose $100 \mathrm{~g}^{-1}$ of pulp.

\section{Vitamin C}

For vitamin $\mathrm{C}$ determination, $2 \mathrm{~g}$ of the sample was homogenized in $20 \mathrm{~mL}$ of $0.5 \%$ oxalic acid using the Polytron crusher. Subsequently, the homogenate was transferred to the stirring table for $30 \mathrm{~min}$ and then filtered (qualitative filter paper, $15 \mathrm{~cm}$ in diameter, Unifil $\left.^{\circledR}\right)$. The extract obtained was used to determine vitamin $\mathrm{C}$. The ascorbic acid content (after oxidation to dehydroascorbic acid) was determined by the colorimetric method using 2,4 dinitrophenylhydrazine according to the method of Strohecker and Henning (1967). The results were expressed as mg of ascorbic acid $100 \mathrm{~g}^{-1}$ of pulp.

\section{Carotenoids}

A combination of solvents was used for the extraction of carotenoids: acetone/petroleum ether. The analysis consisted of sampling and sample preparation, extraction and partition with a solvent, saponification and washing, solvent concentration, chromatographic separation, and identification and quantification with a spectrophotometer. The extraction of carotenoids was performed according to Rodriguez-Amaya (2001). The sample $(5 \mathrm{~g})$ was kept in a flask in the dark, and $20 \mathrm{~mL}$ of cold acetone (P.A.) was added. The contents were stirred for $20 \mathrm{~min}$ and filtered in an Erlenmeyer Flask with the aid of a filter paper. The sample was then washed with acetone until the residue left on the filter paper turned transparent (washed thrice with $20 \mathrm{~mL}, 5 \mathrm{~mL}$, and 15 $\mathrm{mL}$ of acetone (P.A.)). The filtrate was transferred to a separating funnel, and the funnel was covered with aluminum foil. Next, $30 \mathrm{~mL}$ of petroleum ether and 70 $\mathrm{mL}$ of distilled water were added to it. The denser liquid was discarded. This procedure was repeated thrice to remove acetone.

The extract was transferred to a $100 \mathrm{~mL}$ volumetric flask, and petroleum ether was added to make the final volume to $100 \mathrm{~mL}$. The contents were filtered again and stored in a dark bottle until their absorbance was recorded. The "white" to reset the equipment was P.A. Carotenoids were quantified using a spectrophotometric method (Rodriguez-Amaya, 2001). Carotenoids like $\alpha$-carotene, $\beta$-carotene, $\delta$-carotene, $\gamma$-carotene, and lycopene were measured at $444 \mathrm{~nm}, 450$ $\mathrm{nm}, 456 \mathrm{~nm}, 462 \mathrm{~nm}$, and $470 \mathrm{~nm}$, respectively. The content of each carotenoid was calculated according to the formula: $\mu \mathrm{g} \mathrm{g}^{-1}=\mathrm{A} \times \mathrm{V} \times 106 / \mathrm{A} 1 \mathrm{~cm}-1 \% \times \mathrm{M} \times$ 100. A was the absorbance of the solution at a specific wavelength, $\mathrm{V}$ was the final solution volume, $\mathrm{A} 1 \mathrm{~cm}-1 \%$ was the coefficient of molar absorptivity of the pigment in a given specific solvent (petroleum ether), and $\mathrm{M}$ was the mass of the sample taken for analysis in g. Results were expressed in $\mu \mathrm{g} 100 \mathrm{~g}^{-1}$ fruit.

\section{Total phenolic content and antioxidant activity}

\section{Extraction}

The extraction was performed according to the methodology adopted by Rufino et al. (2010). For this, 1 $\mathrm{g}$ of the sample was weighed in a $50 \mathrm{~mL}$ beaker, and 10 $\mathrm{mL}$ of $50 \%$ methanol was added to it; the solution was homogenized and left to stand for $20 \mathrm{~min}$ in the dark. Later, the solution was incubated in an ultrasound bath for $15 \mathrm{~min}$ and filtered (paper qualitative filter, $15 \mathrm{~cm}$ in diameter, Unifil $^{\mathbb{R}}$ ); the supernatant was transferred to a dark flask. To the residue of the first extraction, $10 \mathrm{~mL}$ of $70 \%$ acetone was added. The solution was homogenized and left to stand for $20 \mathrm{~min}$ in the dark. Subsequently, it was incubated in an ultrasound bath for $15 \mathrm{~min}$ and then filtered (qualitative filter paper, $15 \mathrm{~cm}$ of diameter, $\mathrm{Unifi}^{\mathbb{}}{ }^{\mathbb{}}$ ). The supernatant was transferred to the dark flask containing the first supernatant, where they were homogenized again. The obtained extract was used to determine the total phenolic content and the antioxidant capacity by the ABTS and FRAP methods.

\section{Total phenolic content}

The total phenolic content was determined by the Folin-Ciocalteu method (Waterhouse, 2002). The blue color produced by the reduction of the Folin-Ciocalteu reagent by the phenols was measured spectrophotometrically at the absorption wavelength of $750 \mathrm{~nm}$. The phenolic content was calculated by the equation of the straight line obtained from the standard curve of gallic acid. The results were expressed in milligrams of gallic acid equivalent (GAE) $100 \mathrm{~g}^{-1}$ pulp. 


\section{Antioxidant activity}

For the determination of the antioxidant activity, the ABTS radical capture method and the iron reduction method (FRAP) were used.

The antioxidant activity by the $\mathrm{ABTS}^{\circ}+$ radical capture method was performed according to Rufino et al. (2007). The $\mathrm{ABTS}^{\circ}+$ radical capture solution was prepared by mixing a $5 \mathrm{~mL}$ stock solution of $7.0 \mathrm{mM}$ ABTS with 88 $\mathrm{mL}$ of $140 \mathrm{mM}$ potassium persulfate solution. The mixture was kept in the dark at room temperature for $16 \mathrm{~h}$. Then, $1 \mathrm{~mL}$ of this mixture was diluted in ethyl alcohol until an absorbance of $0.70 \mathrm{~nm} \pm 0.05 \mathrm{~nm}$ was obtained at $734 \mathrm{~nm}$.

The absorbance $(734 \mathrm{~nm})$ of the samples was determined at room temperature after 6 min of reaction time. Trolox (6-Hydroxy-2,5,7,8-tetramethylchroman-2carboxylic acid) was used as the reference antioxidant. The results were expressed in $\mu \mathrm{M}$ of Trolox $\mathrm{g}^{-1}$.

The total antioxidant activity by the FRAP method was performed according to Rufino et al. (2006). The FRAP reagent was obtained from the combination of $25 \mathrm{~mL}$ of $0.3 \mathrm{M}$ acetate buffer, $2.5 \mathrm{~mL}$ of a $10 \mathrm{mM}$ TPTZ solution, and $2.5 \mathrm{~mL}$ of a $20 \mathrm{mM}$ aqueous solution of ferric chloride.

The absorbance $(595 \mathrm{~nm})$ of the samples was determined after 30 min of reaction time in a water bath at $37^{\circ} \mathrm{C}$. Ferrous sulfate was used as a reference. The results were expressed as $\mu \mathrm{M}$ ferrous sulfate $\mathrm{g}^{-1}$.

\section{Statistical analysis}

For the analyses of longitudinal and transverse diameter, fresh mass, pulp yield, and staining and firmness,
30 replications per stage of maturation were used. For other analyses, ten replicates per stage of maturation were used. The design was completely randomized, the data were analyzed using the R software v. 3.5.2 (R Core Team, 2019), and the means were compared by the Student's t-test considering $p<0.05$ (Ferreira; Cavalcanti; Nogueira, 2014) as significant.

\section{RESULTS AND DISCUSSION}

The fruits of C. rufa presented increased longitudinal and transverse diameters after ripening, and this was accompanied by an increase in their mass (Table 1). The pulp yield in the mature fruits was $51.35 \%$.

It was possible to identify the color development associated with maturation (Table 1). In the mature fruits of Campomanesia cambesedeana, the coloration was darker $\left(\mathrm{L}^{*}=26.09\right)$ while Campomanesia pubescens changed from a darker $\left(\mathrm{L}^{*}=4.65\right)$ to a lighter color $\left(\mathrm{L}^{*}=36.80\right)$ during development (Morzelle et al., 2015; Silva et al., 2009). No representative changes were observed in the a* coordinate between the immature and mature fruits, and the fruits remained in the green region. However, the $\mathrm{b}^{*}$ coordinate showed an increased intensity in the yellow region (Table 1, Figure 1).

The values of ${ }^{\circ} \mathrm{h}$ (hue angle) indicated that the coloration of the fruits was between pure yellow and pure green. The color changed from green to yellowishgreen with maturation, thus demonstrating an increased chromaticity with maturation (Table 1).

Table 1: Longitudinal and transverse diameters, fresh mass, $L^{*}, a^{*}, b^{*}, h, C^{*}$, firmness, total and soluble pectin in the immature and mature fresh C. rufa fruits.

\begin{tabular}{|c|c|c|c|}
\hline & Immature fruit & Mature fruit & p-value \\
\hline Longitudinal diameter (mm) & 23.76 & 28.03 & $5.08 \times 10^{-10 *}$ \\
\hline Transverse diameter $(\mathrm{mm})$ & 24.39 & 27.14 & $2.36 \times 10^{-07 *}$ \\
\hline Fresh mass (g) & 6.54 & 10.88 & $1.02 \times 10^{-14 *}$ \\
\hline$L^{*}$ & 42.94 & 49.14 & $6.31 \times 10^{-05 *}$ \\
\hline$a^{*}$ & -15.73 & -16.06 & 0.58 \\
\hline$b^{*}$ & 25.11 & 34.26 & $8.59 \times 10^{-09 *}$ \\
\hline $\mathrm{h}$ & 122.43 & 115.73 & $4.22 \times 10^{-11 *}$ \\
\hline$C^{*}$ & 29.39 & 37.90 & $1.08 \times 10^{-07 *}$ \\
\hline Firmness (N) & $12.65 \mathrm{a}$ & 1.27 & $3.34 \times 10^{-12 *}$ \\
\hline Total pectin (mg $\left.100 \mathrm{~g}^{-1}\right)$ & 860.05 & 1246.35 & $1.11 \times 10^{-04 *}$ \\
\hline Soluble pectin (mg $100 \mathrm{~g}^{-1}$ ) & 93.79 & 195.93 & $4.67 \times 10^{-05 *}$ \\
\hline
\end{tabular}

* Means differ significantly from each other, as determined by the Student t-test with a 5\% probability. 
C. pubescens fruits also showed increased yellowing during maturation that was different from the reddish color of mature $C$. cambessedeana fruits. For $C$. phaea fruits, the green color prevailed with decreased gloss and increased opacity with ripening (Silva et al., 2009; Morzelle et al., 2015; Bianchini et al., 2016).

The firmness values of the C. rufa fruits decreased during ripening; the values were $12.65 \mathrm{~N}$ and $1.27 \mathrm{~N}$ in the immature and mature fruits, respectively (Table 1 , Figure 1). Firmness value is an important attribute of fruits for the industry chain because it directly affects the fruit quality, consumer preference, transportability, and shelf life. Moreover, it also affects the ability of the cultivars to be machine harvested and in reducing the financial and labor costs (Li et al., 2018; Cappai et al., 2018).

Pectic substances are the main components responsible for the change in the texture of fruits and vegetables (Huang et al., 2019). The immature and mature fruits showed a high total pectin content (860.05 and

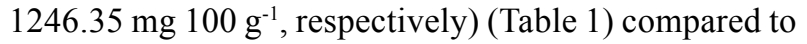

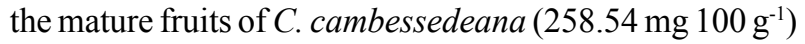

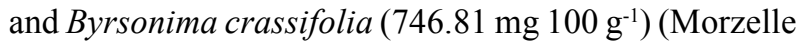
et al., 2015). Similarly, the soluble pectin content in the mature fruits of C. rufa was $195.93 \mathrm{mg} 100 \mathrm{~g}^{-1}$, whereas

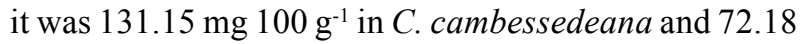
$\mathrm{mg} 100 \mathrm{~g}^{-1}$ in B. crassifolia mature fruits (Morzelle et al., 2015). Pectin gets solubilized with ripening and makes the fruit softer. This explains the increase in the soluble pectin concentration in the mature fruit of C. rufa compared to that in the immature fruits (Morzelle et al., 2015) (Table 1).

The $\mathrm{pH}$ values decreased from 3.60 to 3.40 with the maturation of C. rufa fruits (Table 2). The mature fruits had higher levels of acidity than those of $C$. cambessedeana (4.25) and similar acidity values to that of the C. lineatifolia (3.47) fruits (Table 2) (Morzelle et al., 2015; Lima et al., 2016). The C. phaea fruits displayed greater acidity (2.80) (Sanches et al., 2016). Thus, there existed a wide variation in the $\mathrm{pH}$ values of the Campomanesia species. It is influenced by environmental factors and maturation stages (Goldoni et al., 2019).

In white-fleshed pitaya (Hylocereus undatus), a linear $\mathrm{pH}$ increase occurred that reached values between 3.06 and 4.5 (Magalhães et al., 2019) with maturation. According to Vallilo et al. (2005), fruits with high acidity are used in the industry to produce sweets. Fruit acidity is due to the presence of organic acids, such as malic and citric acids present in most mature fruits (Batista-Silva et al., 2018).

Despite the variation in the $\mathrm{pH}$ between the two stages, no difference was observed in the titratable acidity (1.22 and $1.21 \%$ citric acid in immature and mature fruits, respectively) (Table 2). These values were lower compared to the $3.0 \%$ value of $C$. phaea but were close to that of $C$. pubescens (approximately $1.5 \%$ ) and higher than that of C. cambessedeana (0.19\%) (Valillo et al., 2005; Silva et al., 2009; Morzelle et al., 2015).

Table 2: Mean values of $\mathrm{pH}$, titratable acidity (AT) expressed as citric acid, soluble solids (SS), SS/AT ratio, proximate composition, total sugars, and calorific value of fresh C. rufa fruits at two maturation stages.

\begin{tabular}{|c|c|c|c|}
\hline & Immature fruit & Mature fruit & $\mathrm{p}$-value \\
\hline $\mathrm{pH}$ & 3.60 & 3.40 & $9.44 \times 10^{-05 *}$ \\
\hline AT (\%) & 1.22 & 1.21 & 0.69 \\
\hline SS (\%) & 8.00 & 10.80 & $1.41 \times 10^{-06 *}$ \\
\hline SS/AT & 6.58 & 8.98 & $1.36 \times 10^{-06 *}$ \\
\hline Moisture $\left(\mathrm{g} 100 \mathrm{~g}^{-1}\right)$ & 79.92 & 78.86 & 0.45 \\
\hline Ethereal extract $\left(\mathrm{g} 100 \mathrm{~g}^{-1}\right) \dagger$ & 0.18 & 0.18 & 0.95 \\
\hline Protein (g $100 \mathrm{~g}^{-1}$ ) & 0.72 & 0.81 & 0.47 \\
\hline Fiber $\left(\mathrm{g} 100 \mathrm{~g}^{-1}\right)$ & 4.28 & 4.56 & 0.32 \\
\hline Mineral residue $\left(\mathrm{g}_{\left.100 \mathrm{~g}^{-1}\right)}\right.$ & 0.52 & 0.61 & 0.03107 \\
\hline NFE (g $\left.100 \mathrm{~g}^{-1}\right)$ & 14.38 & 14.98 & 0.57 \\
\hline Total sugars (g $\left.100 \mathrm{~g}^{-1}\right)$ & 1.22 & 6.88 & $2.20 \times 10^{-16 *}$ \\
\hline Calorific value (kcal $100 \mathrm{~g}^{-1}$ ) & 62.01 & 64.76 & 0.54 \\
\hline
\end{tabular}

* Means differ significantly from each other, as determined by the Student's t-test with a 5\% probability. ${ }^{\text {D Dry weight. }}$ 
The content of soluble solids increased as the green fruits ripened into the mature fruits (from 8.0 to $10.8 \%$, respectively) (Table 2). These values were lower than those found in the accessions of $C$. phaea (12.50 to $13.30 \%)$ and C. lineatifolia (11.55\%) (Bianchini et al., 2016; Lima et al., 2016).

The SS/AT ratio is one of the best ways to evaluate sugar content (Teerachaichayut; Ho, 2017). The SS/AT ratio increased in the mature fruits as compared with the green fruits (Table 2). SS increased gradually with the development of the fruit, whereas AT decreased (Sanches et al., 2016).

The high moisture value seen in $C$. rufa was closer to that observed in C. cambessedeana $(77.02 \mathrm{~g}$

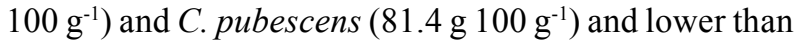

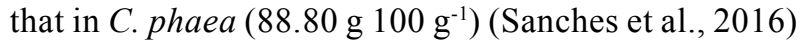
(Table 2). The C. rufa stages did not show differences in their moisture content (Table 2). Thus, in general, the fruits of the Campomanesia genera displayed a high moisture value (De Paulo et al., 2020). Factors such as plant age, water availability, fertilization, and climatic conditions may influence the moisture content (Sanches et al., 2016).

Considering the levels of ethereal extract and protein, the values obtained for $C$. rufa were lower than $1.0 \%$ and did not differ between the immature and mature fruits (Table 2). C. phaea presented low protein content $(0.44 \%)$ and higher lipid content $(1.53 \%)$. C. xanthocarpa presented higher levels of protein $(1.1 \%)$ and lipids $(1.9 \%)$ similar to the values of $C$. cambessedeana for proteins (1.43\%) and lipids (1.32\%) (Vallilo et al., 2005; Vallilo et al., 2008; Morzelle et al., 2015).

The crude fiber content in C. rufa did not differ between the immature and mature stages (Table 2). The values were

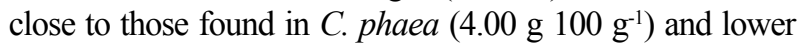

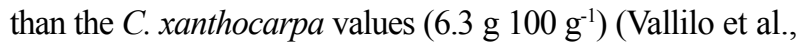
2005; Vallilo et al., 2008). According to the Collegiate Board Resolution (RDC) No. 54/12 of the National Health Surveillance Agency (ANVISA), a good source of crude

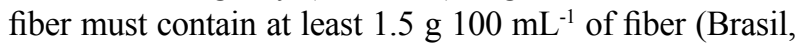
2012).

The mineral residue content did not differ between the immature and the mature fruit (Table 2) and presented

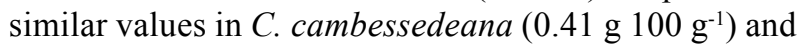

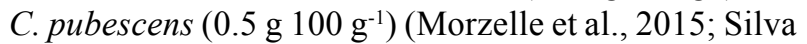
et al., 2009). Fruits are important sources of essential elements and minerals consumed in the human diet (Marles, 2017).

The nitrogen-free extract (NFE) differed

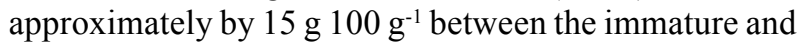

mature fruits of C. rufa (Table 2). In C. cambessedeana,

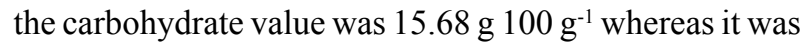

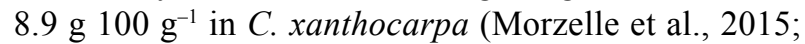
Vallilo et al., 2008). The NFE, represented by glycols like sugars and starch, can include soluble fibers in the case of fruits. Since the sugar content in the C. rufa fruits ranged from 1.22 to 6.88 , it was suggested that these fruits also contained soluble fiber that was not determined as crude fiber. Therefore, the presence of starch could not be ruled out.

The caloric value of $C$. rufa (Table 2) was higher

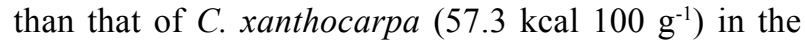
mature fruits (Vallilo et al., 2008). The low caloric value of $C$. xanthocarpa was due to the high moisture content and consequent decrease in the concentration of sugars, lipids, and proteins (Vallilo et al., 2008); this applies to the C. rufa fruits as well.

There was a decrease in the content of $\alpha$ and $\beta$-carotenes and an increase in $\gamma$-carotene content with the ripening of the housekeeper fruits. However, no difference was detected for $\delta$-carotene and lycopene between the immature and mature fruits (Table 3 ). $\alpha$-carotene was most abundant in the green fruits, and $\beta$-carotene was most abundant in the mature fruits (Table 3). $\beta$-carotene deserves attention because it has a higher pro-vitamin A activity (Reksamunandar et al., 2017).

In Psidium guajava var. Paluma, the contents of $\beta$-carotene (366.3 $\left.\mu \mathrm{g} 100 \mathrm{~g}^{-1}\right)$, and lycopene (6999.3 $\mu \mathrm{g} 100 \mathrm{~g}^{-1}$ ) were higher than those in the C. rufa fruits (Table 3). Mangifera indica L. var. Tommy Atkins presented higher $\beta$-carotene content $\left(1557.1 \mu \mathrm{g} 100 \mathrm{~g}^{-1}\right)$ and lower lycopene content $\left(77.2 \mu \mathrm{g} 100 \mathrm{~g}^{-1}\right)$ (Oliveira et al., 2011) than that of the C. rufa fruits (Table 3). Carotenoids have antioxidant properties with functional potential for the prevention of non-transmissible chronic diseases such as cancer and cardiovascular diseases. Lycopene is one of the most studied carotenoids in this sense (Müller et al., 2016). However, the fruits of $C$. rufa generally do not stand out as sources of carotenoids compared to the fruits known to be rich in carotenoids.

The total phenolic value of $C$. rufa was higher

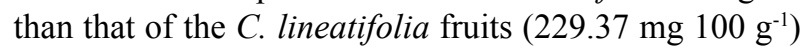
(Lima et al., 2016) (Table 3). The phenolic content was comparable to that of fruits traditionally considered rich in these compounds, such as strawberry and grape. Considering seven varieties of strawberry and grape, the phenolic content ranged from 205 to $318 \mathrm{mg} 100 \mathrm{~g}$

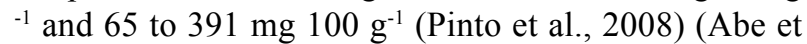
al., 2007), respectively. Phenolic compounds are mainly 
responsible for the color, smell, and protection of fruits and flowers (Martins; Barros; Ferreira, 2016). Moreover, the role of phenolic compounds lies in the stabilization and oxidation of lipids. Thus, they are directly related to antioxidant activity (Araújo; Souza, 2018). Despite each class of phenolic compounds being mainly responsible for specific bioactivity, they commonly evidence polyvalent reactions (Martins; Barros; Ferreira, 2016).

The ascorbic acid value of $C$. rufa exceeded that of C. phaea (33 mg $\left.100 \mathrm{~g}^{-1}\right)$ and C. lineatifolia $(74.44$ $\mathrm{mg} 100 \mathrm{~g}^{-1}$ ) but was lesser than that of $C$. cambessedeana (383.33 mg $100 \mathrm{~g}^{-1}$ ) (Vallilo et al., 2005; Lima et al., 2016; Morzelle et al., 2015). Ramful et al. (2011) classified the fruits into three categories according to their ascorbic acid content: low ( $\left.<30 \mathrm{mg} 100 \mathrm{~g} \mathrm{~g}^{-1}\right)$, medium (30-50 mg

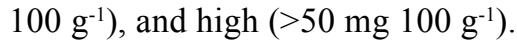

The vitamin C content of $C$. rufa was higher than that of several traditional fruits such as Citrus aurantium L. (125.76 mg $100 \mathrm{~g}^{-1}$ ) (Silva Júnior et al., 2010) and seven cultivars of strawberries that ranged from 65.0 to $112.0 \mathrm{mg} 100 \mathrm{~g}^{-1}$ (Table 3) (Da Silva Pinto; Laojolo; Genovese, 2008). However, the vitamin C content was similar to that of the Hancornia speciose fruit $(260 \mathrm{mg}$ $100 \mathrm{~g}^{-1}$ ) (Silva et al., 2017).
The values of the antioxidant activity detected by the ABTS radical capture method were higher than those found in the natural fruits of Malpighia emarginata $\left(1336.42 \mu \mathrm{M} \mathrm{g} \mathrm{g}^{-1}\right)$, Anacardium occidentale $(254.34 \mu \mathrm{M}$ $\left.\mathrm{g}^{-1}\right)$, and Psidium guajava $\left(130.77 \mu \mathrm{M} \mathrm{g}^{-1}\right)$ (Freire et al., 2013). These values also surpassed those found in the epicarp (543.18 $\left.\mu \mathrm{M} \mathrm{g}^{-1}\right)$ and in the mesocarp $(1,230.00$ $\mu \mathrm{M} \mathrm{g}^{-1}$ ) of Caryocar brasiliense (Morais et al., 2013).

The antioxidant activity did not differ between the green and the mature fruits (Table 3 ) when detected by the iron reduction method (FRAP). The values found were lower than those found in the mesocarp $(2085.70 \mu \mathrm{M}$ $\left.\mathrm{g}^{-1}\right)$ of $C$. brasiliense and higher than those in the epicarp $\left(14.99 \mu \mathrm{M} \mathrm{g}^{-1}\right)$ of $C$. brasiliense and the pulp of Byrsonima verbascifolia (148.42 $\left.\mu \mathrm{M} \mathrm{g}^{-1}\right)$ (Morais et al., 2013).

The C. rufa fruit can be considered an important source of bioactive compounds since it presents high phenolic compounds, ascorbic acid levels, and antioxidant capacity (De Paulo et al., 2020). The consumption of high antioxidant foods is necessary to prevent damage caused by free radicals as these antioxidants help in neutralizing the free radicals (Alkadi, 2020). However, the overload of free radicals over time may become irreversible and lead to certain diseases (Schiassi et al., 2018).

Table 3: Mean values of carotenoids, total phenolics, vitamin C (ascorbic acid), and antioxidants, as determined by the method of $\mathrm{ABTS}^{\circ}+$ radical capture expressed in Trolox and by the iron reduction method (FRAP) expressed in ferrous sulfate of fresh weight in C. rufa fruits.

\begin{tabular}{|c|c|c|c|}
\hline & Immature fruit & Mature fruit & $\mathrm{p}$-value \\
\hline a- carotene $\left(\mu g_{\left.100 g^{-1}\right)}\right.$ & $279.84 a$ & $240.32 b$ & $2.31 \times 10^{-15 *}$ \\
\hline$\beta$ - carotene $\left(\mu \mathrm{g} 100 \mathrm{~g}^{-1}\right)$ & $257.74 a$ & $247.94 b$ & $8.44 \times 10^{-08 *}$ \\
\hline$\delta$ - carotene $\left(\mu \mathrm{g} 100 \mathrm{~g}^{-1}\right)$ & $139.40 a$ & $143.89 a$ & 0.1267 \\
\hline$y$ - carotene $\left(\mu g_{\left.100 g^{-1}\right)}\right.$ & $142.50 \mathrm{~b}$ & $152.81 a$ & $9.73 \times 10^{-11 *}$ \\
\hline Lycopene $\left(\mu \mathrm{g} 100 \mathrm{~g}^{-1}\right)$ & $136.38 a$ & $128.04 a$ & $9.28 \times 10^{-11 *}$ \\
\hline Total polyphenols (mg $100 \mathrm{~g}^{-1}$ ) & $311.40 a$ & $312.47 a$ & 0.9305 \\
\hline Vitamin C (mg $\left.100 \mathrm{~g}^{-1}\right)$ & $279.08 a$ & $263.60 a$ & 0.5606 \\
\hline ABTS $\left(\mu \mathrm{M}\right.$ trolox $\left.g^{-1}\right)$ & $1985.54 a$ & $1862.81 a$ & 0.07427 \\
\hline $\operatorname{FRAP}\left(\mu \mathrm{M}\right.$ ferrous sulfate $\left.g^{-1}\right)$ & $1397.40 a$ & $1443.47 a$ & 0.141 \\
\hline
\end{tabular}

* Means differ significantly from each other, as determined by the Student's t-test with a 5\% probability. 


\section{CONCLUSIONS}

C. rufa fruits are succulent, and their maturation is marked by a color change from green to yellowish-green and an increase in pectin solubilization and soluble solids content. The fruits have a low caloric value, high levels of crude fiber, vitamin $\mathrm{C}$, polyphenols, and high antioxidant activity under in vitro conditions. Moreover, the presence of high pectin levels and low $\mathrm{pH}$ indicates a potential for industrial use in the manufacturing of gels and jellies. These results suggest that $C$. rufa fruits with good nutritional value have the potential for additional studies on bioactive compounds such as polyphenols, and their biological properties need to be investigated under in vivo conditions.

\section{ACKNOWLEDGMENTS}

To CNPq (National Council for Scientific and Technological Development) and FAPEMIG (Research SupportbFoundation of the State Minas Gerais), which partially funded this research.

\section{REFERENCES}

$A B E, L$. T. et al. Compostos fenólicos e capacidade antioxidante de cultivares de uvas Vitis labrusca L. e Vitis vinifera L. Ciência e Tecnologia de Alimentos, 27(2):394-400, 2007.

ALKADI, H. A review on free radicals and antioxidants. Infectious Disorders-Drug Targets (Formerly Current Drug Targets-Infectious Disorders), 20(1):16-26, 2020.

ARAÚJO, A. C. M. A. et al. Bioactive compounds and chemical composition of Brazilian Cerrado fruits' wastes: pequi almonds, murici, and sweet passionfruit seeds. Food Science and Technology, 38:203-214, 2018.

ARAÚJO, E. F. L.; SOUZA, E. R. B. Phenology and reproduction of Campomanesia adamantium (Cambess.) O. Berg (Myrtaceae). Scientific Electronic Archives, 11(2):166$175,2018$.

ARRUDA, H. S.; PASTORE, G. M. Araticum (Annona crassiflora Mart.) as a source of nutrients and bioactive compounds for food and non-food purposes: A comprehensive review. Food Research International, 123:450-480, 2019.

ASSOCIATION OF OFFICIAL ANALYTICAL CHEMISTRY - AOAC. Official methods of analysis. 19th ed. Gaithersburg, 2012. 3000p.

BATISTA-SILVA, W. et al. Modifications in organic acid profiles during fruit development and ripening: Correlation or causation? Frontiers in Plant Science, 9:e1689, 2018.
BIANCHINI, F. G. et al. Caracterização morfológica e química de frutos de cambucizeiro. Bragantia, 75(1):10-18, 2016.

BITTER, T.; MUIR, H. M. A modified uronic acid carbazole reaction. Analytical Biochemistry, 4(4):330-334, 1962.

BRASIL. Resolução da Diretoria Colegiada - RDC $\mathbf{N}^{\circ} \mathbf{5 4}$, de 12 de novembro de 2012. Ministério da Saúde - Agência Nacional de Vigilância Sanitária, 2012. Available at: <http://bvsms.saude.gov.br/bvs/saudelegis/anvisa/2012/ rdc0054_12_11_2012.html>. Access in: March, 14, 2020.

CAPPAI, F. et al. Molecular and genetic bases of fruit firmness variation in blueberry: A review. Agronomy, 8(9)1-20, 2018.

CARDOZO, C. M. L. et al. Therapeutic potential of Brazilian Cerrado Campomanesia species on metabolic dysfunctions. Molecules, 23(9):e2336, 2018.

CARVALHO, J. T. de G. de et al. Medicinal plants from Brazilian Cerrado: Antioxidant and anticancer potential and protection against chemotherapy toxicity. Oxidative Medicine and Cellular Longevity, 2019:1-16, 2019.

DA SILVA, É. R. et al. Anti-inflammatory evaluation and toxicological analysis of Campomanesia xanthocarpa Berg. Inflammation, 39(4):1462-1468, 2016.

DA SILVA PINTO, M.; LAJOLO, F. M.; GENOVESE, M. I. Bioactive compounds and quantification of total ellagic acid in strawberries (Fragaria $\mathrm{x}$ ananassa Duch.). Food Chemistry, 107(4):1629-1635, 2008.

DE ANDRADE SILVA, C. A.; FONSECA, G. G. Brazilian savannah fruits: Characteristics, properties, and potential applications. Food Science and Biotechnology, 25(5):1225-1232, 2016.

DE ANGELIS, R. C. Fisiologia da nutrição: Fundamentos para nutrição e desnutrição. São Paulo: Edart, v. 1, p.43-53, 1977.

DE PAULO F. D. et al. A critical review of some fruit trees from the myrtaceae family as promising sources for food applications with functional claims. Food chemistry, 306:e125630, 2020.

DE SOUZA DUARTE, L. et al. Campomanesia genus: A literature review of nonvolatile secondary metabolites, phytochemistry, popular use, biological activities, and toxicology. Eclética Química Journal, 45(2):12-22, 2020.

EMER, A. et al. The physicochemical properties of fruits and seed germination of Campomanesia aurea O. Berg. Acta Scientiarum - Biological Sciences, 40:e35007, 2018.

FERREIRA, E. B.; CAVALCANTI, P. P.; NOGUEIRA, D. A. ExpDes: An R Package for ANOVA and Experimental Designs. Applied Mathematics, 5(19): 2952-2958, 2014. 
FREIRE, J. M. et al. Quantificação de compostos fenólicos e ácido ascórbico em frutos e polpas congeladas de acerola, caju, goiaba e morango. Ciência Rural, 43(12):2291-2295, 2013.

GOLDONI, J. et al. Physicochemical characterization of fruits of Campomanesia guazumifolia (Cambess.) O. Berg (Myrtaceae). Acta Scientiarum. Biological Sciences, 41(1):e45923, 2019.

HUANG, W. et al. Morphology and cell wall composition changes in lignified cells from loquat fruit during postharvest storage. Postharvest Biology and Technology, 157:112, 2019.

INSTITUTO ADOLFO LUTZ - IAL. Métodos físico-químicos para análise de alimentos. 4. ed. Brasília: Ministério da Saúde. 2005. 1018p.

INTERNATIONAL UNION FOR CONSERVATION OF NATURE IUCN. The IUCN red list of threatened species. 1998. Version 2020-2. Available in: <https://www.iucnredlist. org/>. Access in: March, 14, 2020.

LI, B. et al. Application of hyperspectral imaging for nondestructive measurement of plum quality attributes. Postharvest Biology and Technology, 141:8-15, 2018.

LIMA, J. S. S. et al. Caracterização físico-química de gabiroba (Campomanesia lineatifolia) e murta (Blepharocalyx salicifolius) nativas da região serrana de Ibiapaba-CE. Revista Caatinga, 29(3):753-757, 2016.

LUZ, L. D. et al. Multiproxy analysis (Phytoliths, stable isotopes, and $c / n$ ) as indicators of paleoenvironmental changes in a Cerrado site, Southern Brazil. Revista Brasileira de Paleontologia, 22(1):15-29, 2019.

MAGALHÃES, D. S. et al. Physical and physicochemical modifications of white-fleshed pitaya throughout its development. Scientia Horticulturae, 243:537-543, 2019.

MARLES, R. J. Mineral nutrient composition of vegetables, fruits and grains: The context of reports of apparent historical declines. Journal of Food Composition and Analysis, 56:93-103, 2017.

MARTINS, N.; BARROS, L.; FERREIRA, I. C. In vivo antioxidant activity of phenolic compounds: Facts and gaps. Trends in Food Science \& Technology, 48:1-12, 2016.

MCCREADY, P. M.; McCOMB, E. A. Extraction and determination of total pectin material. Analytical Chemistry, 24(12):15861588, 1952.

McGUIRE, R. G. Reporting of objective color mensurements. HortScience, 27(12):1254-1255, 1992.
MORAIS, M. L. et al. Determinação do potencial antioxidante in vitro de frutos do cerrado brasileiro. Revista Brasileira de Fruticultura, 35(2):355-360, 2013.

MORZELLE, M. C. et al. Caracterização química e física de frutos de curriola, gabiroba e murici provenientes do cerrado brasileiro. Revista Brasileira de Fruticultura, 37(1):96103, 2015.

MÜLLER, L. et al. Lycopene and its antioxidant role in the prevention of cardiovascular diseases: A critical review. Critical Reviews in Food Science and Nutrition, 56(11):1868-1879, 2016.

NELSON, N. A photometric adaptation of somogyi method for the determination of glucose. Journal of Biological Chemistry, 135:135-375, 1944.

NEVES, L. C. et al. Post-harvest nutraceutical behaviour during ripening and senescence of 8 highly perishable fruit species from the Northern Brazilian Amazon region. Food Chemistry, 174:188-196, 2015.

OLIVEIRA, D. S. et al. Vitamina C, carotenoides, fenólicos totais e atividade antioxidante de goiaba, manga e mamão procedentes da Ceasa do Estado de Minas Gerais. Acta Scientiarum Health Sciences, 33(1):89-98, 2011.

PINTO M. S. et al. Functionality of bioactive compounds in Brazilian strawberry (Fragaria $\mathrm{x}$ ananassa Duch.) cultivars: Evaluation of hyperglycemia and hypertension potential using in vitro models. Journal Agriculture and Food Chemistry, 56(12):4386-92, 2008.

R CORE TEAM. R: A language and environment for statistical computing. R Foundation for Statistical Computing, Vienna, Austria, 2019. Available in: <https://www.R-project.org/>. Access in: September, 29, 2020.

RAMFUL, D. et al. Polyphenol composition, vitamin C content and antioxidant capacity of Mauritian citrus fruit pulps. Food Research International, 44(7):20882099, 2011.

REFLORA. Campomanesia. In: Flora do Brasil 2020 em construção. Jardim Botânico do Rio de Janeiro. 2020. Available in: <http://floradobrasil.jbrj.gov.br/reflora/ floradobrasil/FB10335>. Access in: March, 09, 2020.

REIS, A. F.; SCHMIELE, M. Características e potencialidades dos frutos do Cerrado na indústria de alimentos. Brazilian Journal of Food Technology, 22:e2017150, 2019.

REKSAMUNANDAR, R. P. et al. Encapsulation of $\beta$-carotene in polyvinylpyrrolidone) (PVP) by electrospinning technique. Procedia Engineering, 170:19-23, 2017. 
RODRIGUEZ-AMAYA, D. B. A guide to carotenoid analysis in foods. Washington: Internacional Life Sciences Institute Press, 2001. 64p.

RUFINO, M. D. S. M. et al. Metodologia científica: Determinação da atividade antioxidante total em frutas pelo método de redução do ferro (FRAP). Embrapa Agroindústria Tropical-Comunicado Técnico. 2006. 4p

RUFINO, M. D. S. M. et al. Metodologia científica: Determinação da atividade antioxidante total em frutas pela captura do radical livre $\mathrm{ABTS}^{\circ}+$. Embrapa Agroindústria TropicalComunicado Técnico. 2007. 4p

RUFINO, M. S. M. et al. Bioactive compounds and antioxidante capacities of 18 no-traditional tropical fruits from Brazil. Food Chemistry, 121(4):996-1002, 2010.

SÁ, S. et al. Phytochemistry and antimicrobial activity of Campomanesia adamantium. Revista Brasileira de Farmacognosia, 28(3):303-311, 2018.

SALMAZZO, G. R. et al. Chemical composition and antiproliferative antioxidant and trypanocidal activities of the fruits from Campomanesia xanthocarpa (Mart.) O. Berg (Myrtaceae). Natural Product Research, 14786427, 2019.

SANCHES, A. M. C. et al. Physicochemical variability of cambuci fruit (Campomanesia phaea) from the same orchard, from different locations and at different ripening stages. Journal of the Science of Food and Agriculture, 97(2):526-535, 2016.

SANT'ANA, C. R. O. et al. In vitro propagation of Campomanesia rufa: An endangered fruit species. Ciência e Agrotecnología, 42(4):372-380, 2018.

SCHIASSI, M. C. E. V. et al. Fruits from the Brazilian Cerrado region: Physico-chemical characterization, bioactive compounds, antioxidant activities, and sensory evaluation. Food Chemistry, 245:305-3110, 2018.
SILVA, A. V. C. et al. Characterization of trees, fruits and genetic diversity in natural populations of mangaba. Ciência e Agrotecnologia, 41(3):255-262, 2017.

SILVA, E. P. D. et al. Caracterização física, química e fisiológica de gabiroba (Campomanesia pubescens) durante o desenvolvimento. Ciência e Tecnologia de Alimentos, 29(4):803-809, 2009.

SILVAJÚNIOR, G. B. et al. Laranja-da-terra: Potential citric fruit for Piauí State. Semina: Ciências Agrárias, 31(3):557-562, 2010.

SILVESTRE, G.J.S.; MIRANDA, S. C.; DE-CARVALHO, P. S. Levantamento das espécies de Myrtaceae Juss. na Serra do Abrante, Palmeiras de Goiás. In: MIRANDA, S. C. et al. (Ed.). Tópicos em conservação e manejo do cerrado: Biodiversidade, solos e uso sustentável. Goiâna: Kelps, p.31-64, 2019.

STROHECKER, R.; HNNEING, H. M. Análisis de vitaminas: Métodos comprobados. Madrid: Paz Montalvo, 1967, 428p.

TEERACHAICHAYUT, S.; HO, H. T. Non-destructive prediction of total soluble solids, titratable acidity and maturity index of limes by near infrared hyperspectral imaging. Postharvest Biology and Technology, 133:20-25, 2017.

VALLILO, M. I. et al. Características físicas e químicas dos frutos do cambucizeiro (Campomanesia phaea). Revista Brasileira de Fruticultura, 27(2):241-244, 2005.

VALLILO, M. I. et al. Composição química dos frutos de Campomanesia xanthocarpa berg-myrtaceae. Ciência e Tecnologia de Alimentos, 28(1):231-237, 2008.

WATERHOUSE, A. L. Determination of total phenolics. In: WROLSTAD, R. E. (Ed.). Current protocols in food analytical chemistry. United States of America: Wiley, p.1073-1080, 2002.

ZUNINGA, A. et al. Capacidade antioxidantes de frutos nativos do Cerrado (Hancornia speciosa, Campomanesia xanthocarpa, Eugenia dysenterica): Uma breve revisão. Desafios, 5(1):128-134, 2018. 